Věda a perspektivy № 6(6) 2021

ISSN 2695-1584 (Print)

ISST 2695-1592 (Online)

https://doi.org/10.52058/2695-1592-2021-6(6)-154-166

\title{
Галина П'ятакова
}

доктор педагогічних наук, доцент, доцент кафедри загальної педагогіки та педагогіки вищої школи факультету педагогічної освіти, Львівський наџіональний університет імені Івана Франка,

м. Львів, Украӥна, e-mail: halyna.pyatakova@lnu.edu.ua https://orcid.org/0000-0003-2914-0843

\section{АКАДЕМІЧНА МОБІЛЬНІСТЬ ЯК СТРАТЕГІЯ ПРОФЕСІЙНОЇ ПІДГОТОВКИ МАГІСТРІВ: НА ПРИКЛАДІ УНІВЕРСИТЕТІВ КРАЇН ВИШЕГРАДСЬКОЇ ГРУПИ}

Анотація. Визначено, що на сучасному етапі у провідних університетах країн Вишеградської групи спостерігалася активізація магістрантів в процесі міжнародної академічної мобільності. Це пов'язано 3 виконанням завдань Болонської реформи, Свропейського Союзу, які зобов'язали провідні інституції досягти $20 \%$ показника участі студентів, магістрантів, докторантів, працівників у програмах академічної мобільності до 2020 року. Навчання на освітніх програмах мобільності дає змогу студентам 3-4 курсів, молодим науковцям отримати нові спеціалізації, а отже й сформувати професійні компетентності, набути досвід виконувати дослідження міжнародного рівня. У сучасних умовах євроінтеграції для вітчизняної вищої школи вивчення такого досвіду $\epsilon$ важливим для подальшого наслідування. Уточнено поняття «мобільність», академічна мобільність», «віртуальна мобільність».

Відмічено, що кожна країна-учасниця В4 має змогу обирати ті освітні програми, які найбільше підходять для студентів.

Виокремлено, що на студентський вибір впливають такі чинники, як: якість університетської освіти в країні призначення; якість диплома, отримання вартісної спеціалізації на ринку праці; мова, на якій викладають в університеті та інформація про його імідж тощо.

Розглянуто особливості включення до програм мобільності ERASMUS, Еразмус+ KA107 студентів країн B4. Акцентовано на програмах NAWA, SYLFF (Польща), CEEPUS (Чехія), CEEPUS, Campus Mundy, Erasmus Credit Mobility (Угорщина), DAAD, CEEPUS, Akcia Rakúsko-Slovensko (Словаччина).

Обгрунтовано досвід участі в програмах академічної мобільності магістрантів та працівників Ягеллонського (JU), Печського (PTE), Масарика (MU), Матея Бела (UMB, м. Банська Бистриця) університетів країн B4.

Доведено, що академічна мобільність $є$ формою інтернаціоналізації 
провідних університетів, інтегральною частиною навчання магістрів 3 визнанням кредитів i оцінок. Університети Чехії, Угорщини, Польщі, Словаччини мають свої стратегії впровадження академічної мобільності у професійну підготовку магістрів.

Ключові слова: академічна мобільність, віртуальна мобільність, магістр, університети, стипендійні освітні програми, інтернаціоналізація, Вишеградська група.

\title{
Halyna Piatakova
}

Doctor of Pedagogical Sciences, associate professor, associate professor of general pedagogy and pedagogy of high school department of the pedagogical education, Ivan Franko national university of Lviv, Lviv, Ukraine, e-mail: halyna.pyatakova@lnu.edu.ua, https://orcid.org/0000-0003-2914-0843

\section{ACADEMIC MOBILITY AS A STRATEGY FOR MASTER'S PROFESSIONAL PREPARATION: ON THE EXAMPLE OF UNIVERSITIES OF VISEGRAD GROUP COUNTRIES}

\begin{abstract}
It is determined that at the present stage in the leading universities of the Visegrad countries there is an intensification of Master's of Art in the process of international academic mobility. This is due to the implementation of the aims of the Bologna Reform, the European Union, which required the leading institutions to achieve $20 \%$ participation of students, Masters of Art, undergraduates, doctoral students, employees in academic mobility programs by 2020. Training in educational mobility programs allows students of 3-4 courses, young scientists to gain new specializations, and thus to form professional competencies, to gain experience in conducting research at the international level. In the current conditions of European integration for the domestic higher school, the acquiring of such experience is important for further imitation. The concepts of "mobility", "academic mobility", "virtual mobility" are specified.

It is noted that each Visegrad four participating country has the opportunity to choose the educational programs that are most suitable for students.

It is pointed out that the student's choice is influenced by such factors as: the quality of university education in the country, the quality of the diploma, obtaining a specialization in the labor market, the language taught at the university and information about its image and more.

The peculiarities of inclusion the students of Visegrad four countries in ERASMUS, Erasmus + KA107 mobility programs are considered. Emphasis is
\end{abstract}

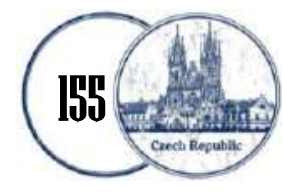


placed on the programs NAWA, SYLFF (Poland), CEEPUS (Czech Republic), CEEPUS, Campus Mundy, Erasmus Credit Mobility (Hungary), DAAD, CEEPUS, Akcia Rakúsko-Slovensko (Slovakia).

The experience of participation in the programs of academic mobility of the Masters of Art and employees of Jagiellonian (JU), Pecs (PTE), Masaryk (MU), Matei Bela (UMB, Banska Bystrica) universities of Visegrad countries is substantiated.

It is proved that academic mobility is a form of internationalization of the leading universities, an integral part of teaching Masters of art with the recognition of credits and grades. The universities of the Czech Republic, Hungary, Poland, and Slovakia have their own strategies for introducing academic mobility into the professional training of Masters of art.

Keywords: academic mobility, virtual mobility, master's degree, universities, scholarship educational programs, internationalization, Visegrad Group.

Постановка проблеми. Сучасним маркером розвитку провідних університетів Свропи є академічна мобільність суб'єктів освітньої діяльності. Участь магістрів у програмах академічної мобільності є ознакою високого рейтингу освітнього закладу, інтернаціоналізації університету, а також рівня процесу підготовки випускників. Чим більше освітніх програм розроблено для іноземних студентів в університеті, впроваджено кращі умови для їхнього навчання, тим вище статус навчального закладу. Кожний провідний університет у країнах В4 сьогодні має змогу відкрито пропонувати своїм студентам обрати ту освітню програму, яка їм підходить, активно популяризує ii на сайті 3-поміж багатьох програм мобільності, ознайомлює 3 вимогами навчання, стажування, відгуками студентів-учасників тощо. Нові перспективи для співпраці в освітній галузі, а отже і для активізації академічної мобільності студентів, магістрантів, аспірантів, викладачів відкриває Європейський простір вищої освіти.

Аналіз останніх досліджень і публікацій. У працях таких науковців, як Т. Гордєєва, О. Гусак, Є. Іванченко, Н. Кожемякіна, Ю. Клименко, Н. Латуша та ін. увагу приділено особливостям формування професійної мобільності у суб'єктів освітнього процесу. У дослідженнях Н. Василенко, Л. Данилова, М. Дмитрієва, Є. Іванченко, І. Хорєва, Л. Хорунжої, Л. Сушенцевої, О. Щербак проаналізовано соціальну, професійну, професійно-педагогічну, віртуальну, академічну мобільності, завдяки яким підвищується якість та ефективність вітчизняної освіти, поширюється позитивний європейський досвід. Разом з тим, проблема аналізу академічної мобільності як стратегії професійної підготовки 
магістрів в університетах країн Вишеградської групи не стала предметом спеціального дослідження.

Мета статті - дослідження освітніх програм академічної мобільності та визначення їхніх головних особливостей як стратегії у професійній підготовці магістрів в університетах країн В4.

Виклад основного матеріалу. $У$ сучасних умовах європеӥзації вищзой освіти активізацію магістрів університетів країн Вишеградської групи за освітніми програмами міжнародної академічної мобільності розглядаємо як приклад для наслідування у вітчизняній вищій школі. Участь в освітніх програмах сприяє формуванню у випускників професійних компетентностей, дає змогу отримати нову спеціалізацію, щзе й досвід долучення до міжнародних досліджень. Якщо поняття "мобільність" можна визначити як здатність особистості до швидкої дії, підготовленість до чогось, здатність до швидкого переміщення, то під академічною мобільністю розуміють можливість для студентів, викладачів, адміністративно-управлінського персоналу інституцій “переміщуватися" з одного ЗВО до іншого як на європейському, так і на національному рівнях. Водночас набуває популярності поняття «віртуальна мобільність» як можливість навчатися, викладати та займатися науковими дослідженнями в іншому закладі освіти засобами дистанційних та телекомунікаційних технологій (дистанційна освіта, електронне навчання, професійна інтернет-комунікація).

Проаналізуємо академічну мобільність як стратегію професійної підготовки магістрів в університетах Чехії, Угорщини, Польщі, Словаччини. Сьогодні академічну мобільність студентів потрібно розглядати як інтегральну частину їхньог навчання 3 визнанням кредитів і оцінок, отриманих під час академічної мобільності.

3-поміж чинників, що впливають на мобільність студентів, визначили якість освіти, яку пропонують університети в країні призначення, якість диплома та подальша його вартість на ринку праці. Важливим для студента $є$ й інформація про імідж країни/ університету, яку можна отримати від інших студентів та у ЗМІ, сформувати власне рішення на основі статистичних даних. Вагомим чинником мотивації для іноземних студентів $є$ і доступність освіти в країні. Основна мотивація навчання за кордоном полягає в розширенні знань 3 певної галузі, що неможливо зробити у своєму університеті, бажання отримати диплом 3 дефіцитної професії. Сума плати за навчання - $\epsilon$ ще одним мотиваційним чинником для магістра. На сучасному етапі багато країн вже організували мовні курси підготовки студентів, які бажають навчатися, або покращити рівень іноземної мови. Тому важливим чинником $є$ і мова навчання. Останнім часом першочерговими чинниками стали політична стабільність країни, а також права іноземців/іноземних студентів, правила імміграції тощо. Не можна оминути і проблему фінансування програми мобільності, оскільки

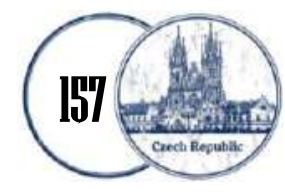


Věda a perspektivy № 6(6) 2021

ISSN 2695-1584 (Print)

ISST 2695-1592 (Online)

іноземні студенти сплачують за навчання в більшості країн самостійно. Отже, потрібно враховувати ще й навчальні гранти, позики, можливість працювати неповний робочий день у країні перебування тощо [1, с. 31].

Результати дослідження 2015 p. (Trends 2015), яке провели в європейських університетах, засвідчують, що мобільність студентів і співробітників стала інтегрованим елементом інтернаціоналізації. Дослідники відмітили, що університети “усвідомили” свій вплив і стратегічний потенціал як для викладання, так і для досліджень. Процес інтернаціоналізації розглядають як механізм підготовки студентів до громадянства в умовах глобалізації та розвитку партнерства та досліджень [2, s. 95-96].

Зазначимо, що кожна країна-учасниця В4 реалізує програму академічної мобільності відповідно до національних відмінностей, характеру діяльності міжнародних інституцій, які координують ці програми, а також статистичних i текстових даних інформаційних баз UNESCO, EUROSTAT, EURYDICE.

Акцентуємо й на ролі флагманської ініціативи “Молодь в дії”, мета якої полягала в підвищенні продуктивності й привабливості європейських вищих навчальних закладів на міжнародному ринку. Зокрема, до 2020 р. перед вищою освітою було висунуто завдання інтегрувати та підвищити мобільність на рівні ЄС університетських та дослідницьких програм ("Erasmus", "Erasmus Mundus", "Tempus", "Marie Curie"), а також їхній взаємозв'язок 3 національними програмами та ресурсами [3].

Оскільки університети країн В4 у своїх довгострокових планах визнали поширення академічної мобільності студентів одним із важливих завдань, розглянемо академічну мобільність як стратегію у процесі професійної підготовки магістрів.

Активно включені у програми мобільності магістранти університетів Чехії. 3-поміж магістрантів гуманітарних спеиіальностей популярною $\epsilon$ стипендійна програма Центральної Свропи - CEEPUS [4].

Особливістю інтернаціоналізації закладів вищої освіти в країні $\epsilon$ розширення міжнародних контактів з провідними світовими інституціями. Так, у Довгостроковому плані на 2014-2020 рр. Університету Масарика (MU) (м. Брно) відповідно до стратегії інтернаціоналізації зазначили необхідність розширення спектра можливостей для студентів та викладачів за кордоном, розроблення навчальних програм, курсів іноземними мовами та проведення інших заходів, які спрямовані на збільшення кількості іноземних студентів та вчених у $\mathrm{MU}$ [5].

3-поміж головних напрямів Відділ міжнародної співпраці Університету Масарика виділив роботу з іноземними партнерами. По-перше, це створення таких акредитованих програм магістерського та докторантського ступенів, які засновані на співпраці двох або більше установ та мають спільну програму. Всі установи, які співпрацюють, несуть відповідальність за виконання дослідження 
повністю, а не лише за окремі розділи акредитованої програми. Завершують дослідження присвоєнням спільного ступеня або декількох ступенів. До таких навчальних програм висувають вимогу - обов'язково мати документ 3 акредитації (за потреби оновлений), а до закладів - угоду про співпрацю.

В Університеті Масарика розрізняють подвійний/багаторазовий ступінь, що дозволяє офіційно присуджувати два/більше національно визнаних диплома двома/більше установами, що входять до спільної програми підготовки випускника. Спільний сmуniнь, єдиний ступінь, надати який можуть щонайменше дві установи за спільною програмою підготовки.

По-друге, відділ міжнародної співпраці Університету працює 3 індивідуальними договорами, які регулюють співпрацю двох закладів та конкретного студента. Цей напрям співпраці в MU включає дослідження подвійного менеджменту (їх також називають cotutelle), угода про співпрацю підтверджує спільне наукове керівництво докторським дослідженням та регулює обов'язки установ щодо оцінювання та захисту дисертації. Є ще й європейський докторат, який відповідно до умов співпраці, визначених Свропейською асоціацією університетів, присвоює звання доктора (Doctor Europaeus) на основі угоди про співпрацю.

Акредитацію має забезпечити факультет Університету, на якому акредитована така освітня програма, у співпраці з зарубіжним закладом. У такому випадку в комісію 3 акредитації разом 3 підписаною угодою про співпрацю між закладами подають заявку на акредитацію програми згідно 3 усіма вимогами і стандартами за зразком методичної інструкції “Акредитація навчальних програм і процедур габілітації в MU”. Таку заявку подають на підпис ректору MU через навчальний відділ університету (програми бакалавріату, магістратури i докторантури) або дослідницький відділ (докторські програми).

Розглянемо особливості академічної мобільності як стратегї в університетах Польщзі. Так, Ягеллонський університет (JU) активно співпрацює 3 понад 40 університетами 323 країн світу. За популяризацію стипендійних програм відповідає департамент міжнародного співробітництва JU. Студенти та магістранти мають змогу взяти участь у програмі стипендій у рамках двостороннього співробітництва - NAWA - Національного агентства 3 питань академічного обміну (Narodowa Agencja Wymiany Akademickiej). Програма спрямована на навчання студентів, магістрантів та молодих дослідників усіх галузей науки, якщо міжнародною угодою не передбачено інше. До прикладу, магістранти філологічних спеціальностей навчаються у Вірменії, Болгарії, Китаї, Чехії, Сгипті, Греції, Ізраїлі, Японії, Казахстані, Монголії, Румунії, Сербії, Словаччині, Словенії, Україні, Угорщині, В’єтнамі, оскільки між вищими закладами цих країн підписані угоди про співпрацю. Пропозиція стосується поїздок на період від п’яти днів до дванадцяти місяців, а

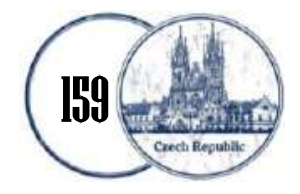


також літніх мовних курсів. Стипендію виплачує польська або приймаюча сторона залежно від умов договору. У межах програми відбувається: проходження стажування; заочне навчання; закінчення вищої освіти (другий цикл або докторантура); очне навчання; збір матеріалів для наукової роботи; участь у літній мовній та культурній школі; проведення навчальних занять та ін. форми наукової чи академічної діяльності, які пов'язані 3 написанням докторських дисертацій, впровадженням дослідження, науковими публікаціями тощо.

До бенефіціара висунуті певні умови: особиста відповідальність за здійснення наукової діяльності, навчання/викладання впродовж впровадження проєкту; не може перебувати поза приймаючим центром більше часу ніж 1/4 від загальної тривалості проєкту (включно конференції, свята, поїздки); повинен мати європейську карту медичного страхування; має своєчасно подати частковий (за необхідності) та підсумковий звіт разом із сертифікатом приймаючого університету про те, що заплановане наукове стажування відбулося; інформує NAWA про зміни в реалізації проєкту, про свої наукові чи навчальні успіхи під час виконання і на етапі звітності та оцінювання, у т. ч. про публікації, зроблені під час заявки на отримання гранту/реалізації проєкту тощо; розміщує всі публікації польською чи англійською мовами, акцентуючи, що це $\epsilon$ результат перебування за програмою Національного агентства 3 питань академічного обміну [6, s. 15-16].

З 1987 року в Ягеллонському університеті працює Стипендійний фонд для молодих лідерів - SYLFF. Програма SYLFF спрямована на підтримку освіти магістрів та докторантів з високим лідерським потенціалом, наукові інтереси яких мають важливий соціальний аспект. Стипендії, які присуджують представникам гуманітарних, соціальних, юридичних, економічних наук та менеджменту, є не лише науковим грантом. Стипендії сприяють виконанню соціально значущих програм, а також дають змогу перебувати в закордонному закладі на навчанні, на курсах, наукових консультаціях тощо. Стипендії SYLFF, пов'язані з виконанням наукових досліджень, призначені для покриття 95\% витрат на участь у програмах навчання приймаючого закладу, реалізацію освітньої програми, витрати на утримання та проїзд, участь у наукових конференціях, що стосуються навчальної програми [7].

Прикладом активізації академічної мобільності у вищій освіті Угорщини $\epsilon$ університет у м. Печ (РТЕ), який має міжнародну репутацію за якість своїх досліджень і викладання на десяти факультетах. Мета Університету РТЕ сприяти мобільності студентів та співробітників, розвинути та поширити міжнародні партнерські зв'язки викладачів та дослідницьку діяльність. Особливостями стратегії Університету РТЕ вважаємо виконання генеральної мети - створення та активізація міжнародного університету. Виконання мети відбувається через завдання: 
- $\quad$ сприяти формуванню у викладачів та магістрантів високих цінностей для проведення досліджень та отримання досвіду міжнародної вищої освіти у всьому світі;

- створити міжнародне середовище за допомогою залучення все більшої кількості міжнародних студентів та міжнародних викладачів, які допомагають створювати партнерські відносини без кордонів.

3 року в рік до РТЕ для вивчення та проведення досліджень приїжджають міжнародні студенти та науковці з інституцій понад 80 країн. За інформацією міжнародного відділу щороку більше 2500 іноземних студентів обирають навчання в університеті. За угодами між університетами та різними міжнародними та регіональними мережами університетів реалізують та підтримують велику кількість партнерських стосунків. Університет РТЕ пропонує широкий спектр програм у рамках міжнародної освіти та навчання, забезпечуючи високий рівень освітніх програм та досліджень [8].

В Університеті РТЕ розроблено понад 50 програм для навчання на різних ступенях та підготовчих курсах, викладання на яких переважно відбувається англійською або німецькою мовами. Міжнародні студенти мають змогу продовжувати навчання на рівні бакалавра, магістра та доктора наук. У партнерстві з 50 установами по всьому світу Університет РТЕ також бере участь у схемах обміну та мобільності, які пропонують студентам та викладачам міжнародний досвід, надають їм нові перспективи особистісного розвитку та розуміння різних культур.

Для активізації міжнародної співпраці в університеті РТЕ, як на рівні університету, так і на факультетах, створено СІС - Центр інтернаціоналізації та зв'язків, який репрезентує Університет за кордоном, а також координує взаємодію 3 міжнародними партнерами. Для підтримки зусиль 3 інтернаціоналізації окремих факультетів СІС тісно співпрацює з міжнародними координаторами.

Головними сферами діяльності СІС є:

- міжуніверситетські угоди, застосовувані як до мобільності студентів, так i співробітників, а також до інших форм співпраці; розширення міжуніверситетської мережі для співпраці 3 престижними інституціями у всьому світі;

- рекрутинг на міжнародні програми, який передбачає активну підтримку факультетів щодо їхньої участі у міжнародних програмах; проведення маркетингових досліджень; зв'язок з кадровими агенціями та контроль маркетингових комунікацій, пов'язаних 3 підбором студентів на університетському рівні; визнає важливість розвитку послуг для іноземних студентів;

- програми мобільності, в яких Університет РТЕ бере активну участь Erasmus+, Campus Mundy, CEEPUS тa Erasmus Credit Mobility);

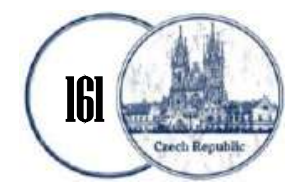


- стипендійне консультування, функцією якого $є$ інформування студентів, членів викладацького та адміністративного персоналу про наявні можливості стипендії за кордоном;

- участь у міжнародних організаціях, головна мета яких в обміні практичним досвідом та створенні нових партнерських відносин. Міжнародні університетські мережі та організації відіграють ключову роль у розширенні міжнародних зв'язків. Університет РТЕ має досвід з проведення щорічних конференцій ректорів Альп-Адріатичного регіону, Дунайської конференції ректорів, зустрічей 3 групою Компостела, університетською мережею європейських столиць культури та Альянсом університетів за демократію (AUDEM) [9].

В Університеті РТЕ англійською мовою розроблені спеціальні програми підготовки "Навчання за кордоном" для іноземних студентів. Така освітня програма надзвичайно гнучка, оскільки дає змогу вивчати дисципліни з різних університетських кафедр, тобто у процесі підготовки задіяно перехресний підхід. Магістрант має змогу створити власну навчальну програму, відповідно до інтересів особистісного розвитку та освітньої програми університету своєї країни. Студентам потрібно обрати дисципліни, вартість яких не менше 20 кредитів за семестр, врахувати, що один курс відповідає двом-дев'яти кредитам. В Угорщині один кредит ECTS дорівнює 30 годинам. Магістрантам радять заздалегідь обговорити кредитний еквівалент 3 власною установою, тому Університет РТЕ пропонує затвердити програми в закладі студента. Наприкінці навчального періоду також виготовляють повну стенограму, де вказані всі навчальні дисципліни, які вивчили магістранти, та всі зароблені бали. Від студентів для участі в програмах "Навчання за кордоном" не вимагають знання угорської мови, оскільки всі курси викладають англійською мовою. Студентів ознайомлюють 3 планами освітнього процесу, канікулярним та сесійним графіками, вимогами до вступу на освітню програму, які висувають іноземним студентам:

•бути студентом університету своєї країни;

-абітурієнти, першою мовою яких $\epsilon$ не англійська мова, мають представити сертифікат про рівень знання мови (IELTS, TOEFL IBT, іспит у Кембриджі та ін.).

Розглянемо особливості академічної мобільності як стратегії в університетах Словаччини. В Університеті Матея Бела (UMB) (м. Банська Бистриця) студенти мають змогу навчатися за стипендіями програм CEEPUS, DAAD, Національною стипендійною програмою та за Австрійсько-Словацькою акційною програмою.

Німецька Служба Академічного Обміну - DAAD - це спільна установа університетів Німеччини, роль якої полягає у розширенні та підтримці співпраці із інституціями зарубіжних країн, зокрема шляхом обміну студентами

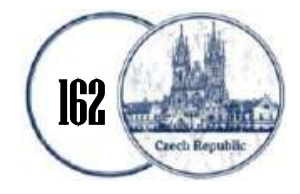


та науковцями. Ця установа надає стипендії на навчання, дослідження, для літніх мовних курсів та для розроблення мистецьких проєктів. Навчальні стипендії призначені для студентів та випускників Університету Матея Бела та $\epsilon$ важливими для них. Стипендії DAAD для дослідження дають докторантам, молодим дослідникам і педагогам, тим, хто вже був учасником цієї стипендії та зацікавленим у докторантурі в Німеччині.

Національну стипендійну програму (NÁRODNÝ ŠTIPENDIJNÝ PROGRAM), яку фінансує Міністерство освіти, науки, досліджень та спорту Словацької Республіки призначають студентам, магістрантам та докторантам словацьких університетів. Стипендія покриває витрати на проживання, навчання магістрам/докторантам, наукового стажування під час докторантури в закордонному університеті. Національна програма стипендій Словацької Республіки також призначена для підтримки мобільності іноземних студентів, магістрантів та докторантів для перебування в університетах Словаччини та науково-дослідних організаціях.

Програма Австрійсько-Словацька акція (Akcia Rakúsko-Slovensko) створена для сприяння співпраці Австрії та Словаччини в галузі вищої освіти, науки та досліджень. Програма призначена для підтримки короткотермінового перебування студентів, переважно випускників, магістрантів та докторантів на навчанні, на літніх мовних курсів, для підготовки дипломних робіт та науководослідних проєктів [10].

Програма CEEPUS, яка також поширена у Словаччині, дає змогу розвивати співпрацю між словацькими та зарубіжними університетами через створення академічних мереж, у межах яких реалізується науково-дослідна співпраця та мобільність студентів, докторантів і викладачів університетів. Пріоритетом програми CEEPUS є розроблення спільних навчальних програм для отримання подвійних/спільних магістерських/докторських дипломів, 3 включенням спільного керівництва магістерськими та докторськими дисертаціями. Програмою CEEPUS також можуть бути організовані екскурсї та літні школи, координаційні зустрічі та мовні курси, які доповнюють професійне та наукове співробітництво між університетами-партнерами.

Всі університети країн Вишеградської групи популяризують програми "Еразмус Мундус", “Еразмус+", "Еразмус+ КА107” - це короткострокові програми мобільності за обміном на навчання. У нових державах-членах ЄС студенти прагнуть здобути міжнародний досвід, оскільки вони можуть ефективно розвивати свої майбутні економічні відносини, збільшити рівень володіння мовою та розширити кругозір. Однією 3 основних причин кількісного зростання учасників програми може бути щорічний грант від ЄС. Також урахування кількості студентів, що виїжджають на навчання за кордон, впливає на обчислення субсидії для університетів країн В4.

За даними дослідників, найбільше подорожують за програмами

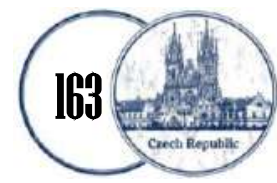


представники соціальних та філологічної (лінгвістичної) галузей. Зазначимо також, що протягом багатьох років регулярно використовували стипендії "Еразмусу" більше жінок, ніж чоловіків. Розподіл студентів-учасників за напрямом навчання відрізняється від розподілу студентів, які подорожують для навчальних цілей. Еразмус вважають піонером у розвитку ресурсів для спільної роботи й організування, зміни ролі студентів та розповсюдження належних практик у системі прийняття рішень. Інструменти підтримки мобільності (додаток до диплома, кредити ECTS тощо), які спочатку діяли як засіб міжнародної мобільності, набули інституційного та системного впливу для сприяння цілям Болонського процесу.

3-поміж цілей міжнародної мобільності студенти виокремили такі:

- прозорість навчальних систем;

- професійне співробітництво, що зосереджується на змісті та приводить до гармонізації структур та видачі дипломів спільних ступенів;

- міжнародне визнання дипломів;

- визнання змісту європейського виміру;

- поліпшення якості вищої освіти [11, о.37].

При Міжнародному Вишеградському фонді діє стипендійна програма, щзо створена для полегшення академічних обмінів шляхом надання фінансової підтримки студентам або дослідникам, які $є$ громадянами країн Східного партнерства. До таких країн разом 3 Україною, належать Вірменія, Азербайджан, Білорусь, Грузія, Молдова. Навчання/дослідження учасників програми відбувається в університетах Чеської Республіки, Угорщини, Польщі та Словаччини - країнах В4. Усі вищі навчальні заклади є акредитованими урядами (міністерствами/відповідальними за вищу освіту) та інститутами академій наук (“університет/установа”) і мають право приймати студентів на навчання. Метою програми стипендій є підтримка мобільності студентів і дослідників 3 цих країн. Програми стипендій V4EaP фінансує Міжнародний Вишеградський фонд. До програм залучені всі країни Вишеградської четвірки. Фондом також розроблені правила програми стипендій V4ЕaP. Відповідно, для фізичних/юридичних осіб, які беруть участь в програмах, розроблено умови, терміни тривалості та фінансування/стипендії [12].

Висновки. Академічна мобільність в інституціях країн Вишеградської групи діє як стратегія в процесі професійної підготовки магістрів. Кожна країна-учасниця В4 пройшла свій шлях інтернаціоналізації та змогла розширити міжнародну співпрацю 3 відомими світовими інституціями. Університети Чехії, Польщі, Угорщини і Словаччини, виконуючи завдання Болонської реформи, Свропейського Союзу, накопичили досвід із залучення магістрів до освітніх програм академічної мобільності. Кожний заклад активно впроваджує інноваційні форми, методи для організування тісної міжнародної співпраці з провідними світовими закладами. 
Шлях розвитку кожного закладу, як і вищої освіти країни-учасниці В4 загалом, в залученні до академічної мобільності суб'єктів освітнього процесу має індивідуальний характер. На сучасному етапі євроінтеграції важливим $\epsilon$ вивчення та імплементація цього досвіду у вітчизняну вищу школу. Розширення участі в програмах академічної мобільності та впровадження їх у процес професійної підготовки магістрантів/докторантів у закладах вищої освіти України потребує вивчення та грунтовного аналізу освітніх програм, які створюють можливості для отримання подвійних дипломів, проходження стажування, долучення до проведення досліджень тощо.

\section{Jimepamypa:}

1. Клименко Ю. А. Професійна мобільність майбутніх учителів у країнах Євросоюзу: автореф. дис. ... канд. пед. наук : 13.00.04/ Ю.А. Клименко. - Умань: УДПУ, 2011. - 23 с.

2. Trends 2015: Learning and teaching in european universities. Retrieved from https://eua.eu/resources/publications/388:trends-2015-learning-and-teaching-in-europeanuniversities. html.

3. П'ятакова Г. П Тенденції дидактичної підготовки магістрів-філологів в університетах країн Вишеградської групи/ Г. П. П’ятакова: [моногр.]. - Львів: Видавничий центр ЛНУ імені Івана Франка, 2020. - 496 с.

4. Masarukova univerzita. Retrieved from https://czs.muni.cz/cs/student-mu/studijnipobyty/ceepus.

5. Masarukova univerzita. Retrieved from https://czs.muni.cz/cs/partneri.

6. Bilateralna-Regulamin. URL: wyjazdy_end. pdf. $31 \mathrm{~s}$.

7. Uniwersytet Jagielloński w Krakowie. Retrieved from https://dwm.uj.edu.pl/inneoferty/stypendia-mniszw/oferta-nawa.

8. PTE. International. Retrieved from https://international.pte.hu/overview.

9. PTE. Study programs, international relations. Retrieved from https:// international.pte.hu /study_programs/ba_international_relations.

10. Univerzita Mateja Bela $\mathrm{v}$ Banskej Bystrici. Retrieved from https://www.umb.sk/ medzinarodne-vztahy/stipendia-a-granty/dalsie-programy-spoluprace.html.

11.Katalin K. Nemzetköziesítés, mobilitás, közös képzések. [W:] Mobilitás Magyarországon Lehetöségek és teendök. Retrieved from http //: bologna_fuzetek_4_issuu.pdf. O. 31-40.

12. .Rules of the V4EaP Scholarship Program Financed by the International Visegrad Fund /Rules - EaP 1.pdf. Retrieved from https://www.visegradfund.org/ archive/documents /visegradscholarship-program.

\section{References:}

1. Klymenko Y.O. (2011). Profesiina mobilnist maibutnih uchuteliv u krainah Eurosouzu. [Professional mobility of the future teachers in the countries of the European Union]. Candidate's thesis. Sumy: SumSU [in Ukrainian].

2. Trends 2015: Learning and teaching in european universities. Retrieved from https://eua.eu/resources/publications/388:trends-2015-learning-and-teaching-in-european-universities. html.

3. Piatakova H.P./ (2020). Tendencii dydactychnoi pidgotovku magistriv-filologiv v universutetah krain Vushegradskoi grupy/ H.P. Piatakova [Tendencies of the didactic preparation of the Masters of Philology on the Visegrad group universities]. monography, Lviv; Ivan Franko national university, 2020

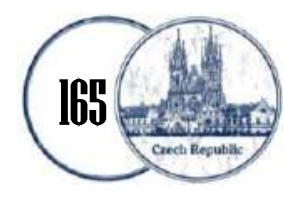


4. Masarukova univerzita. Retrieved from https://czs.muni.cz/cs/student-mu/studijnipobyty/ceepus. [Czeh Republic]/

5. Masarukova univerzita. Retrieved from https://czs.muni.cz/cs/partneri. .[Czeh Republic].

6. Bilateralna-Regulamin. URL: wyjazdy_end. pdf. 31 s. (дата звернення 08.02 2020).

7. Uniwersytet Jagielloński w Krakowie. Retrieved from https://dwm.uj.edu.pl/inneoferty/stypendia-mniszw/oferta-nawa. [Poland].

8. PTE. International. Retrieved from https://international.pte.hu/overview. [Hungary].

9. PTE. Study programs, international relations. Retrieved from https:// international.pte.hu/ study_programs/ba_international_relations. [Hungary].

10. Univerzita Mateja Bela v Banskej Bystrici. Retrieved from https://www.umb.sk/ medzinarodne-vztahy/stipendia-a-granty/dalsie-programy-spoluprace.html. [Slovakia].

11. Katalin K. Nemzetköziesítés, mobilitás, közös képzések. [W:] Mobilitás Magyarországon Lehetöségek és teendök. Retrieved from http //: bologna_fuzetek_4_issuu.pdf. O. 31-40.[Poland]

12. Rules of the V4EaP Scholarship Program Financed by the International Visegrad Fund /Rules - EaP 1.pdf. Retrieved from https://www.visegradfund.org/ archive/documents/visegradscholarship-program. 